\title{
Inspection of the Transportation of Dangerous Goods by Inland Waterways in Hungary
}

\author{
KÁTAI-URBÁN Lajos ${ }^{1}$, KISS Enikö²
}

\begin{abstract}
It has not even been two years since disaster management took over the enforce- ment process of the transportation of dangerous goods by inland waterways. The international regulations of the transportation of dangerous goods by inland wa- terways are recorded in the European Agreement concerning the International Carriage of Dangerous Goods by Inland Waterways (ADN). The most important goal of control and inspection is to get the regulations enforced in order to ensure transportation safety. The main goals of this article are to evaluate the experience, present the achievements and make proposals on how to correct the mistakes and deficiencies.
\end{abstract}

\section{Regulation of the transportation of dangerous goods over inland waterways}

The inspection of the transportation of dangerous goods by inland waterways is still a new task for the disaster management authority, as this has been within the competence of the disaster management authority for only the last two years. Because of this we have rather limited information and experience, however this is a very important area and even within such a short time there is a significant improvement in the adherence to the rules related to the transportation of dangerous goods over waterways.

On the Danube River there is almost only international transportation of dangerous goods, and most of the ships arrive from outside of the member states of the European Union at the Hungarian sections of the Danube River. The ships cross the Schengen borders at the Border Port of Mohács both from the Serbian and the Croatian side, with arriving ships entering the area of the European Union. As on public roads, on the water inspectors carry out strict inspections, thus Hungary has a major responsibility for the completion of authority tasks.

There is usually a high quantity of goods transported simultaneously on one ship. As an example shows, only one ship used for the transportation of goods with a capacity of 1500 tons, the transportation of goods is by far more economical compared to rail or road trans- portation. A train consisting of 38 pieces of 40 ton wagons is easier to imagine than a convoy of 50 pieces of 30 ton trucks transporting the same quantity of goods. From this, one can also conclude that if a ship transports such a high quantity of goods at once, then an anomaly aboard a ship is a high risks. For this reason the inspection of the transportation of dangerous goods over waterways by the disaster management authority is of special importance, as by sorting out anomalies various risks can significantly be reduced. [1]

National University of Public Service; Institute for Disaster Management, Katai.Lajos@uni-nke.hu

2 Central Office for Administrative and Electronic Public Services, Criminal Records Authority 
The authors collected experience from the employees of the branch offices of the Disaster Management Directorate of Budapest, of the ship inspection office of the Branch Office in Mohács, of the Dangerous Shipments Chief Inspectorate of the Ministry of the Interior (MI) National Directorate General for Disaster Management (NDGDM) and of Hungária Danger- ous Goods Engineering Office (Hungária Veszélyes-áru® Mérnöki Iroda Kft. — HVESZ).

Dangerous goods can be transported on public roads, by rail, over waterways or by air- plane. There are various transportation regulations applying to the various transportation methods: $A D N$, $A D R$ (European Agreement Concerning the International Carriage of Dan- gerous Goods by Road), IMSBC Code (International Maritime Solid Bulk Cargoes Code), ICAO TI (International Civil Aviation Organization Technical Instructions for the Safe Trans- port of Dangerous Goods by Air)/IATA DGR (International Air Transport Association Dan- gerous Goods Regulations), IMDG Code (International Maritime Dangerous Goods Code) and RID (Regulations Concerning the International Carriage of Dangerous Goods by Rail). The tasks of the disaster management authority related to the transportation of dangerous goods are completed in line with the Hungarian and international legal regulations. For the ships transporting dangerous goods over the Hungarian section of the Danube River it is compulsory to know, apply and stick to the European Agreement concerning the Internation- al Carriage of Dangerous Goods by Inland Waterways. The provisions of ADN, ADR and RID are similar and contain cross-references.

In addition to ADR ADN and RID inspections within the competence of disaster manage- ment organizations. [2]

Simultaneously with the changes effected on January 1, 2012 new tasks have been dele- gated to the disaster management authority as well. As of that time not only the tasks related to the inspection of the road transportation of dangerous goods, but also the inspection of rail and water transport is within the competence of the disaster management authority. Within the frame of the preparation for the implementation of new tasks, since 2011, there have been several training courses related to rail, water and air transportation of dangerous goods. [3]

In order to complete authority inspections, affairs and ad hoc coordination tasks, it is ex- tremely important to cooperate closely with other co-authorities. The Dangerous Shipments Chief Department, starting 2012, participated in the implementation and coordination of a nu- merous series of actions organized by co-authorities aimed at the inspection of the transport of dangerous goods. On the side of co-authorities the competent organizations of the National Transportation Authority, the National Tax and Excise Bureau, the National Police Office, and the Water Police Office of the Police Office of Budapest participated in the inspections.

According to the declaration of the MI NDGDM the cooperation with the co-authorities was great and efficient in every case, therefore, in coordination with the National Chief In- spectorate for Industrial Safety and the Dangerous Shipments Chief Inspectorate the series of national actions continued in the year 2013 as well. The aim of the actions is to identify dan- gerous illegal international and national shipments, to unveil hidden or illegitimate shipments of dangerous goods and to follow such shipments up in the individual transportation sectors, paying special attention to the inspection of shipments entering the area of Hungary. [3]

The rules of the standardized procedure applying to the inspection of dangerous goods and to the fines to be imposed in the course of the actions of the professional disaster man- agement organization and the amount of fines that can be imposed in case of the violation of the rules and the general rules of authority tasks related to fines are stipulated in Gov. Decree No. 312/2011. (XII. 23.). 
The local organization of the disaster management authority is authorized to carry out the inspection. The local organization of the disaster management authority has the right to carry out inspections within the competence area of other disaster management authorities based on previous approval. The amendment of the Gov. Decree No. $312 / 2011$ (XII. 23.) took effect on July 4, 2013, for this reason, based on previous statistics, reports, in line with the legal regulations then in effect, also the regional organization is mentioned as an inspecting organization.

In case of the violation of rules related to the transportation of dangerous goods, in the first instance the local organization of the disaster management authority carrying out the inspection, in the second instance the regional organization leading the first instance local organization of the disaster management authority has the right to impose fines and to take other actions. ${ }^{3}$

The competent authorities, in terms of being responsible for the location where the ship- ment crosses the border are: at the time of the announcement of the transportation of dan- gerous goods, in case of loading in Hungary, the regional organization; in case of loading abroad, the organization of the disaster management authority.

In case of the transportation of dangerous goods over waterways the competence area of the disaster management authority extends until the state border of the adjacent state is locat- ed along a common section of the river.

The code of procedure is defined in the order No. 127/2012 of the director-general of MI NDGDM that took effect on January 1, 2013. The effect of the order extends also to the central organization of the professional disaster management organization (MI NDGDM), its regional organizations (directorates), and local organizations (local offices). $[5]$

\section{Forwarding over the Hungarian section of the Danube River}

With regard to the type of the shipment we differentiate between ships transporting dry goods and liquid cargo. Dry goods can be bulk shipment (transportation of solid materials as bulk loads without packaging), consignment (consisting of packaging units ready for dispatch, large packaging or IBC and its content) and Ro-Ro (Roll-on, Roll-off, combined road and water transport). Liquid goods are transported in various types of tankers. The types of tank- ers are specified in the ADN rules.

Ships can be divided into further groups according to their propelling force, thus there can be power propelled ships, self-propelled ships, tow boats, track-boats without propelling, and barges. It is important to know the type of the ship at the time of the inspection, because there are different regulations in place for the different types of ships, for example the rele- vant provisions of the leak alarm plan.

On the Hungarian section of the Danube River the water transportation of dangerous goods takes place almost exclusively in tankers. The reason is that the highest turnover re- sults from the transportation of fuels, mainly fuel oil (UN 1202) and petrol (UN 1203). Occa- sionally bulk load is transported, this being in most cases fertilizers covered by ADR. Ships transporting dangerous goods as consignment have not been inspected yet in the area of Hungary during the inspection period. [6]

3 BM OKF Veszélyes Szállítmányok Főosztály adatai alapján 


\section{Regional level of inspection}

In Hungary, in the authority inspection of the water transportation of dangerous goods, on the basis of the data of navigability (e.g. riverbed, water level and ship traffic) only the counties along the Danube River are affected. Thus the inspections are within the competence of Győr- Moson-Sopron, Komárom-Esztergom, Pest, Fejér, Bács-Kiskun, Tolna and Baranya County, and of Budapest. Water inspection in Baranya County and in Budapest is of special signifi- cance. In Baranya County, in the city of Mohács is located at the crossing point of the border with Serbia, Croatia and Hungary, where, without any exception every ship leaving/arriving is subject to a comprehensive inspection as this is the beginning and the end of the Schengen zone.

Budapest is an area of paramount importance because of its disaster management ranking and due to its special central role. The main reason is that there is a significant concentration of important and protected public institutions (e.g. ministries, bureaus, the Hungarian Par- liament), Seveso II. upper tier establishments, residential buildings and public institutions of protected persons, establishments involved in international water transport are present here and the number of inhabitants is very high. Furthermore the inspection shall take place with- out hindering the transportation and at the present only the Disaster Management Directorate of Budapest has a fireboat. [7]

\section{National annual inspection statistics}

In the course of our research, in addition to the practical parts, MI NDGDM, the Dangerous Shipments Chief Department has made available the national statistics of the year 2012 to us. In the course of 2012 a total of 43 resolutions were adopted: 42 in Baranya County and 1 in Tolna County. From the 43 resolutions only 3 reached the authority of second, most of the other 40 have been acknowledged and paid for. During 2012 there was a total of 315 water in- spections. More than $50 \%$ of the inspections took place in Baranya County (184 inspections) but there were many inspections (40 inspections) in Budapest as well. ${ }^{4}$

The number of inspections at sites was much lower. The reason is that there are not sites everywhere to inspect, this activity is absolutely unnecessary in certain counties. All over Hungary there was a total of 20 site inspections, $25 \%$ in Budapest.

In the course of 2012 all over Hungary the staff of the disaster management authority inspected a total of 1995 ships and 1199 of these ships transported dangerous goods. Most ships were inspected in Baranya County (1 479 ships in total), of which $61 \%$ transported dangerous goods. In Budapest the ratio was similar, here a total of 139 ships were inspected and $59 \%$ of them were subject to ADN.

The extraordinary character of the work of the authority is supported by the fact that only

$5 \%$ of the ships inspected during 2012 were from Hungary. 33\% of the ships arrived from EU member states and $62 \%$ from states outside of the EU. The ratio expressed as percentage indicates that inspection in Hungary plays an important role, because most of the ships in transit in Hungary arrive from outside of the European Union and this is also the point of their entrance to the Schengen zone.

\footnotetext{
4 BM OKF Veszélyes Szállítmányok Főosztály adatai alapján
} 
On the basis of the statistics around the year 2012 only $3 \%$ of the defective transporting units arrived from Hungary, the ratio of defective ships from EU member states is rather high (44\%) and 53\% come from outside of EU member states.

Based on the experience collected so far it can be stated that a total of 100 million tons of dangerous goods are transported on the Danube River, ships transporting dangerous goods subject to ADN log in via the NAVINFO system. As mentioned earlier, most ships transport fuels, fuel oil, Petrol. As of January 1, 2012 the disaster management authority inspects in the area of eight disaster management county directorates along the Danube River. [5]

\section{Summary}

Fortunately, on the Hungarian section of the Danube River accidents happening in the course of the transportation of dangerous goods are not typical. There were only two accidents be- cause of bedding during the last two years, but there were no dangerous substances released into the environment.

There are similarities between the experiences collected in Budapest and at border ports. Most of the procedures resulted from the shortcomings, full or partial lack of documents or fire extinguishers, and of personal protective equipment, but statistics show improving tendencies.

All in all it can be stated that during the last one and a half years there were major changes in the adherence to the rules pertaining to the water transportation of dangerous goods. The reason is that the disaster management authority, since the take-over of the task, pay special attention to the inspections, making a good use of the experience collected earlier during the inspection of road transports.

Within a short time safety on the ships improved significantly, as the ships of most for- warding companies enter Hungary, and thus the European Union not only once, but every week or every month. In order to avoid sanctions resulting from anomalies identified in the beginning, these companies try to rectify the anomalies and in addition to the remedy of shortcomings to exercise continuous control over the assets and documents, and have them revised as needed, and to extend the expiry date of documents still in due time.

News about inspections are spread also internationally, therefore it happens only rarely today that a ship, needing to be turned back because of its extremely bad condition, tries to enter the territory of Hungary. However we still identify shortcomings in new arrivals or on ships arriving after the swap of captains.

In case continuous control would be terminated, then probably the safety of water trans- portation would diminish to the level before 2012, as most of the forwarding companies stick to the rules in order to ensure conformity with the rules when inspected and to avoid fines. Of course this does not apply to water transportation only, the same would probably happen to road and rail transportation as well.

Cooperation with co-authorities is excellent, which is very important in this area, as the common actions and in case of the ship inspector's duty and everyday work is performed to- gether with them. Cooperation is excellent both as far as information flow and the completion of tasks is concerned.

In the course of the inspection the lack of the possibility to hold ships back in case of the removal of the addressee is a problem. This could be resolved by the amendment of regula- tion No. 312/2011 and the fine could most probably be delivered. 
KÁTAI-URBÁN Lajos, KISS Enikő: Inspection of the Transportation of Dangerous Goods...

The training courses and methodological guides of authority inspectors are extremely use- ful. The employees of the disaster management spoke out positively on this. Due to changes regarding training courses listed on the National Register of Vocational Qualifications the training course "administrator of dangerous goods" was cancelled from the register. At the present the deficiencies of the training system are not yet remedied, but the necessary knowl- edge can be acquired at safety consultation courses. A permanent solution should be found as soon as possible, either by introducing new training courses or by reactivating old courses.

The problems resulting from the lack of IMDG and the solution proposed calling for the translation of the IMDG and for the adaptation of the same to the legal regulations is also related to the topic of courses, or alternatively, there should be language courses (English) with professional curriculum organized and the possibility of further education abroad should be ensured. In addition at least one copy of the codex should be available in the language of professional language training at each branch office.

For the improvement of the professional level of inspections in the future the training course specializing in industrial safety at the National University of Public Service is a great basis, and the university notes published by the Disaster Management Institute of the Uni- versity as gap-filling literature also facilitates the work of industrial safety specialists. [8]

\section{References}

[1] LOÓS Z. (2013): Veszélyes áru szállitás — Hatósági feladatok. Előadás

[2] MUHORAY Á. (2012): A katasztrófavédelem aktuális feladatai. Mindenki hadtudománya elöadássorozat. Elöadás

[3] BOGNÁR B., VASS Gy., KOZMA S.: A BM OKF Országos Iparbiztonsági Főfelügyelőség szakterületeinek bemutatása. Új Magyar Közigazgatás, 56 (2012) 19-27.

[4] KOZMA S. (2012): A veszélyes áru szállitás ellenőrzési és szankcionálási tevékenységének tervezése és végrehajtása. Előadás

[5] Veszélyes áruk vizi szállitásának aktuális kérdései. ADN 2013 és az IMDG Code 36-12, HVESZ, 2013.

[6] Adatszolgáltatás. Fővárosi Katasztrófavédelmi Igazgatóság, Közép-Pesti Katasztrófavédelmi Kirendeltség. Budapest 2013.

[7] BOGNÁR B. (et al.) (2013): Iparbiztonságtan I.: Kézikönyv az iparbiztonsági üzemeltetői és hatósági feladatok ellátásához. Kátai-Urbán L. (Ed.), Budapest: Nemzeti Közszolgálati és Tankönyvkiadó, ISBN 9786155344121 